\title{
Ancient Glaciation of the Caucasus
}

\author{
Khazaradze Revaz, Kharadze Koba, Tsikarishvili Kukuri, Chartolani Giorgi \\ Vakhushti Bagrationi Institute of Geography, Ivane Javakhishvili Tbilisi State University, Tbilisi, Georgia \\ Email: giorgi.chartolani@tsu.ge, revaz.khazaradze@tsu.ge
}

How to cite this paper: Revaz, K., Koba, K., Kukuri, T. and Giorgi, C. (2018) Ancient Glaciation of the Caucasus. Open Journal of Geology, 8, 56-64. https://doi.org/10.4236/ojg.2018.81004

Received: December 8, 2017

Accepted: January 20, 2018

Published: January 23, 2018

Copyright $\odot 2018$ by authors and Scientific Research Publishing Inc. This work is licensed under the Creative Commons Attribution International License (CC BY 4.0).

http://creativecommons.org/licenses/by/4.0/ c) (i) Open Access

\begin{abstract}
The paper deals with important, different views on the old glaciation of the Caucasus based on the literary sources and the latest data obtained through the expeditions. Our researches are mostly of complex character where petrographic, palynological and paleontological methods are widely used. The petrographic method allowed us to connect block debris of the moraine with the main centers and to determine the directions of the glaciers movement and their distribution boundaries. The palynological method was used to determine the genesis of loose sediments considered as moraines and their sedimentation conditions. The palynological spectrum of deposits shows that they are river sediments and their sedimentation took place under humid, moderately warm climate conditions that is not associated with glaciation.
\end{abstract}

\section{Keywords}

Petrography, Palynology, Genesis, Sedimentation

\section{Introduction}

The study of the Caucasian Isthmus, from the point of view of paleoglaciation, began in the second part of the XIX century [1]. At the end of the century paleogeographical study of the Caucasus was carried out under the influence of West European ideas based on the study of the Alps. Since 1956 the West European ideas have been subjected to criticism and the first attempts have been made to work out the objective scheme of the Caucasian glaciation [2]. However, the Alpine tradition still exists in the works of some investigators of the Caucasus. The main summits of the Great Caucasus by their absolute height exceed the Pleistocene conditions for glaciers development in the Caucasus (comparative simplicity of the mountains belt's plain) and Great Caucasus climate is not, and never favourable for the existence of such a thick glacial cover, as in the Alps. 
The Caucasus is located to the South from the Alps by $5^{\circ}$ on the average, and consequently is warmer by several degrees. Moreover, the Eastern and partly the central regions of the Great Caucasus are characterized by dry, continental climate unfavourable for snow accumulation.

There are many controversial views on the ancient glaciations of the Caucasus. It is quite obvious that common opinion on the multiplicity and boundaries of maximum spread of the Caucasus ancient glaciation does not exist. The height of the vertical movement of vegetation zones is to be verified, to determine most glaciers movement directions radical changes are required. The latest history of glaciation of the Caucasus has been considered critically in the paper and the authors specified paleogeographical statements that have been mechanically conveyed from the schemes established for North Europe. Our conclusions are based on the results of long-term and thorough study of the Caucasus and comprise many novelties for the investigators of the ancient glaciation epoch. Analogous integrated study was carried out on the Western and Eastern Caucasus as well [3] [4] [5] [6] [7]. There were discussed issues of paleoclimate variations and changes of geographical environment in the Late Pleistocene and Holocene (Figure 1).

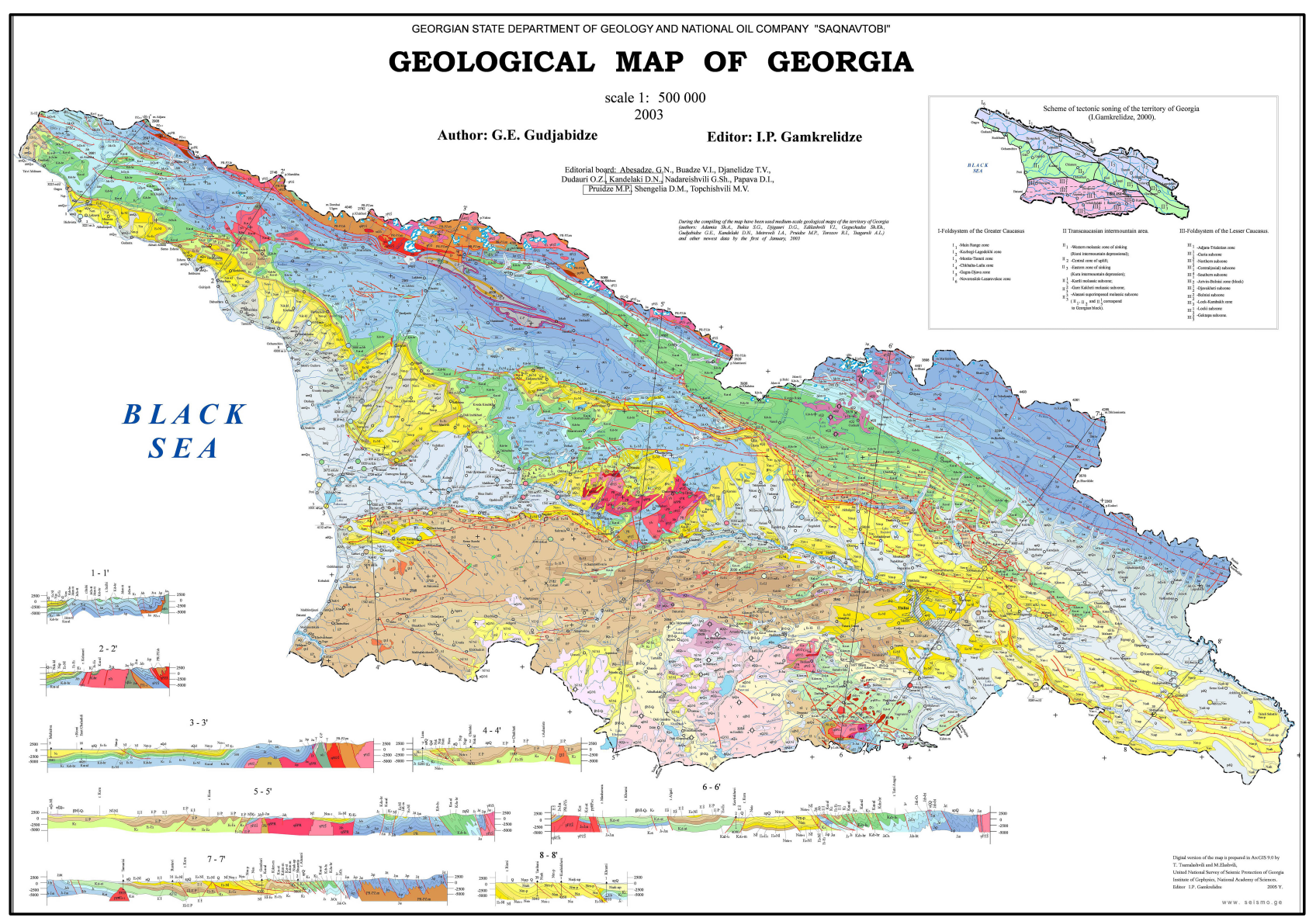

Figure 1. Geological map of Georgia (Gudjabidze G.E., 2003, Georgian State Department of Geology and National oil company "Saknavtobi") [8]. 


\section{Methods of Research}

The paper is valuable as during the researches petrographic and palynologic methods were used in order to resolve the issues raised in the paper. Petrographic method was first used for the Caucasus by us. It gave possibility to associate the boulders observed in the gorges with petrologically similar parent rocks (312 samples were treated) making easier to determine directions and boundaries of glaciers spreading [3] [9].

Palynological method (590 samples for pollen analyses) was applied for the establishment of genesis of fossilized plant spectrum in the loose series and sedimentation conditions. In some cases, suites considered as moraine sediments turned out to be fluvial and has no connection with glaciers.

\section{Discussion}

Going on to the past glaciation of the Caucasus, it should be noted that the advance of the local glaciers down to the populated mountain valleys is reflected in the mountaineers' folklore. Svanetian poems recited by Nizaradze and put down by A. Krasnov tell us about the advance of Namkvami glacier from the Enguri upper reaches through the community of Ushguli, up to the village of Davberi of Kala community, i.e. at a distance of $17 \mathrm{~km} \mathrm{[10].} \mathrm{This} \mathrm{legend} \mathrm{is} \mathrm{based} \mathrm{either}$ upon the observation of the Svans of the signs of the ancient glaciation (troughs, moraines, blocks) located below the contemporary glaciation, or upon a recollection of a concrete event known by generations (one of the phases of glaciation, the "minor glacial epoch" in the XVII-XIX centuries, or the Middle Holocene stage). The adherents of the application of the Alpine paleoglacial schemes to the Caucasus, with A. L. Reinghard [11] [12], P.V. Fedorov, A.P. Getner [13] at the head, admitted, and even now admit that during the glaciation stages of the Quaternary period the snow-line in the Caucasian mountains was 1200 1300 lower $\mathrm{m}$ in comparison with the present one. The glaciers completely filled the river valleys of the Greater Caucasus, passed the foothills and covered some of the piedmont valleys. It is supposed that, the strongest glaciation took place in the Terek (the northern slope) and Kodori (the southern slope of the Greater Caucasus) river basins as well as in the Enguri and Rioni basins. According to the above mentioned scientists "The Great Terek glacier" was even spread along the Osetian plain and reached the Kabardian highland, thus coming down to 500 - $600 \mathrm{~m}$ above the sea level. According to the same scientists, the Kodori glacier reached the boundary of mountainous belt and there (at $300-400 \mathrm{~m}$ above the sea level) joined a tributary-the Amtkeli glacier. These and some other ideas about the huge ancient glaciers of the Great Caucasus are corroborated by the presence of coarse detrital material, resembling glacier moraines.

The latest investigations of many scientists (L.A. Vardaniants [14], L. I. Maruashvili [15], A.N. Berezniakov [16], I.M. Velikovskaia, A.V. Kozhevnkov [17], K. N. Pafenholts [18], R.D. Khazaradze [9] [19] [20] etc.) proved, that sediments of different genesis, such as mudflow in the first place (as well as volcanic, de- 
luvial, colluvial etc.) were taken for glacial moraines. The actual mudflow activity in the Caucasus is still rather intensive (especially in the east). In the past it was even more intensive, due to the tectonic shoves, rock falls and catastrophic thaw of large glaciers. In some regions such as Kazbegi, it was even more intensive due to volcanism. Hot lava streams thawed huge snow and ice bodies. The mud-stone streams (lahars) gushed out along the valleys and carried away huge stone blocks. One of the largest boulders in the Caucasus- "Ermolov's block" (dimensions $39 \times 15 \times 13 \mathrm{~m}$ ), lying in the Terek river bed, at the end of the Dariali gorge, was displaced by the mudflow in 1832, before the people's eyes. Blocks that littered the Kabardo Upland and Osetia sloping plain were shifted at the beginning of the Pleistocene-during the development of the Valakhian orogenic phase, when the abrupt uplift of the Great Caucasus took place with simultaneous downwarping of the present day Kabardo upland and the pre-Terek river dipping at a high angle. At the same time the gigantic volcanoes vere active in the Kazbegi region, that is proved by petrographical contents of the Rukhs-dzuar suite. In the Kodori river basin no volcanoes occurred and the boulders are smaller, than in Kazbegi. They were shifted by ordinary (not volcanoglacial) mudflow that was caused, either by rapid uplift of the Chkalta and Bzibi ridges during the same Valakhian phaze, or by the intensive thaw of the glaciers located higher on their slopes. The original erratic boulders of glacial genesis at the Caucasus were moved lower $1000 \mathrm{~m}$ above the sea level, only in Abkhazia and Svanetia. The largest of them are found in Khevsuretia, in the upper reaches of the Khevsuretia-Aragvi, at the foot of a diabasic massif of Chaukhi, at the altitude $1800-2000 \mathrm{~m}$. Some of them are larger than the erratic blocks in the Alps. Large glacier boulders, almost of the same size are found in Svanetia (Perkhuliskva near village Khalde), in Racha ("Datusela" on the Lechkumi ridge at Chutkharo mountain) etc.

On the Caucasus ancient snow-line, determined according to the traces of glaciers, was located $700-1000 \mathrm{~m}$ lower than the contemporary one. In Abkhazia it went to $2000-2100 \mathrm{~m}$ above the sea level, to the east it raised up in parallel with the present snow-line and reached $2900-3000 \mathrm{~m}$ in Tushetia. On the Ajaria-Imeretia Range of the Lesser Caucasus, where glaciers don't exist nowadays, the snow-line was at $2200-2300 \mathrm{~m}$, while in the depth of Anticaucasus ${ }^{1}$ in Armenia and the south-west Azerbaijan, it raised up to $2900-3100 \mathrm{~m}$ above the sea level.

In the Eastern Caucasus the glaciers generally never slide lower than $2000 \mathrm{~m}$. However, at separate massifs, such as the Chaukhi and Didgverdi they reached the levels $1500-1800 \mathrm{~m}$. The area and length of the largest Pleistocene glaciers of the Greater Caucasus exceeded the present day glaciation of the Alps, but still was less than that of the Pamirs and Hindukush. The length of the largest Pleistocene glaciers of the Caucasus rarely exceeded $40 \mathrm{~km}$. The greatest glaciers of that epoch, were located in the same place where now the largest glaciers of the

${ }^{1}$ Anticaucasus_the uplifted country to the south of Kolkhida, Kartli and Azerbaijan lowlands. It includes the Lesser Caucasus and the Transcaucasian Upland. 
Caucasus are-in Balkaretia, in the valleys of two Chereks (on the northern slope of the Central Caucasus) as well as in the Teberda valley (Western Caucasus), where contemporary glaciation is poor. On the opposite, southern slope in Svanetia the length of Pleistocene glaciers reached $30-35 \mathrm{~km}$ and only Nenskra glacier was over $40 \mathrm{~km}$ long. Glaciers in other regions of the Great Caucasus were considerably smaller than these "champions". In the Western Caucasus, the length of the Bzibi glacier was $17 \mathrm{~km}$, South-Ptyshi_14 km, Chkhalta_20 km, Sakeni_32 km. In the Eastern Caucasus only Abudelauri glacier was up to $12 \mathrm{~km}$ [21].

Valley glaciers of the cold epoch had larger dimension and more complicated character than the contemporary ones. Their polysynthetic character was more obvious, in general. However, the former idea on huge, complex, branched glacial systems often proves incorrect. For example in Terek, Enguri and Kodori basins, the largest glacial systems were supposed to exist, but later due to thorough investigations the paleogeographic picture was changed (see below the ideas on the ancient glaciation of these basins).

Contemporary glaciers of the Caucasus almost never cross saddles of mountain ranges. The powerful (up to $300-400 \mathrm{~m}$ ) Pleistocene glaciers, in some places crossed the ridges confining their basins (transfluent glaciers). The Ancient Mulakhi glacier crossed over the Ugviri pass, Chkhalta glacier-Amtkeli pass, Sabertsi_Igliis gele, Abudelauri-Blosgele pass, etc. Petrographic composition of the erratic material confirms these facts.

Contemporary glaciers of the Caucasus do not overpass the side valleys and never crossed the main valleys anywhere. In the Pleistocene, such phenomena occurred in many regions of the Greater Caucasus. That was clearly expressed in the Upper Svanetia, where five glaciers from side valleys (Mulakhi, Dolra, Baki, Nakra and Nenskra) passed into the Enguri valley from the right, while from the left advanced only one (Lailachala) glacier. The Enguri valley, below the Ipari community, was free of ice. The similar situation occurred in the other river basins_Rioni, Chkhalta, Liakhvi, Terek, Big Laba etc.

At present, it is observed that in some regions of the Caucasus, the maximum development of glaciers and the minimum absolute height of their lower termini do not coincide with hypsometrically well developed basins. For example, as the highest peaks of the Caucasus are the Shkhara and Dzangha (5000 - $5200 \mathrm{~m}$ from the sea level), the glaciers coming from there should be the longest and most powerful. In reality, on the southern slope of the Greater Caucasus the Chalaati glacier slides down lower ( $1800 \mathrm{~m}$ from the sea level) than the other ones, almost into the forest zone. The above situation may be induced by microclimate regime and exposition of glaciers [9]. In the Pleistocene this discrepancy was more evident. In Svanetia the longest Pleistocene glacier_Nenskra_was fed from the mountains up to $4000 \mathrm{~m}$ high. In the Eastern Caucasus the Didgverdi glacier starting from Didgverdi massif (the absolute height only $3334 \mathrm{~m}$ ), was larger than the glaciers of the mountain Shaviklde (3576 m), Khochaldag (3484 m), etc. The reasons of such a discrepancy are the following: 1) topographic conditions 
of snow accumulation in combination with climate, and 2) low position of maximum precipitation level during glacial epochs (at present it is located at 2500 - $3000 \mathrm{~m}$, on average).

Poor development of glacial relief forms in the areas of gigantic extinct volcanoes of the Greater Caucasus-Elbrus and Kazbegi are to be noted. Development of troughs, moraines, and other traces of glaciation around these massifs does not correspond to the thickness and large extension of their firns. Troughs are poorly expressed along the Baksani and Terek river valleys. This fact suggests an idea that the Elbrus and Kazbegi cones were uplifted not before, but after the maximum glaciation epoch. However, poor development of trough valleys in these regions can be partly explained by filling of many troughs with lava streams, and that contemporary rivers flow along the young canyons, being cut down along the contact line of lavas with the rocks of their substratum.

The geographical range of the Pleistocene glaciation of the Greater Caucasus begins in the west, at the meridian of the health resort Sochi_in the region of Fisht and Oshten mountains $\left(39^{\circ} 31^{\prime}\right.$ the east longitude) and spreads to the east for $760 \mathrm{~km}$, up to the mountain of Babadag, at the meridian of town Kjurdamir in Azerbaijan ( $\left.47^{\circ} 31^{\prime}\right)$.

From the region of Fisht-Oshten, up to the upper reaches of the river Bzibi $(125 \mathrm{~km})$, where contemporary glaciation is almost absent, the largest Pleistocene glaciers were those of the rivers Mzimta, Bzibi and Avadkhara on the southern slope, and White and Great Laba on the northern one. Their length ranged between $12-33 \mathrm{~km}$. Low altitudes of these mountains (up to $3000-3500$ m) didn't hinder the development of glaciers, since it was compensated by humid climate and low location of the maximum precipitation belt in the glacial epoch. The ancient glaciers slid down also from the side ridges of Gagra and Bzibi on the southern slope and from the forerange on the northern slope where at present insignificant remnants of eternal ice and snow are preserved.

To the east from the upper reaches of river Bzibi $\left(41^{\circ} 00^{\prime}\right.$ E.L.), up to the junction of the Main and Kodori Ranges ( $42^{\circ} 00^{\prime}$ E.L., distance $75 \mathrm{~km}$ ), large Pleistocene glaciers slided down Teberda river on the northern slope, and Sakeni on the southern one, their length ranged between 10 - $45 \mathrm{~km}$. Presently the Main Range is armoured with an unbroken cover of glaciers. The maximum height of mountains in this area is up to $4046 \mathrm{~m}$ (Dombai-Ulgen), climate is humid. The side ranges (Chkhalta and Kodori on the southern slope, Lateral glacier on the northern slope) also underwent glaciation. The contemporary glaciation is represented there by small separated glaciers. The problem of the Ancient glaciation of the Kodori river basin is debatable. A part of the scientists (Reinghard [12], Feodorov [13], Tsereteli [22] and others) admit that the Amtkeli glacier probably slid down to the altitude of $300-400 \mathrm{~m}$ above the sea level. Others (Maruashvili [23], Khazaradze [9], Bereznjakov [16], Velikovskaja, Kozhevnkov [17] neglect the above, and consider, that the glacier ended one km higher. The rudaceous material in the area of Teberda, considered by the first group of scientists as moraines, is actually the outwash of glaciers mudflow. 
To the east of the Kodori Range up to the Mamisoni Pass ( $43^{\circ} 30^{\prime}$ E.L., distance $146 \mathrm{~km}$ ), spreads that part of the Central Caucasus, where the Main Range reaches the maximum height (up to 4500 - $5200 \mathrm{~m}$ ) and bears on its slopes the complete cover of large glaciers. There the Forerange is crowned with summits of Elbrus (5633 m), Dikhtau (5203 m), Koshtantau (5201 m), Dzangitau (5049 $\mathrm{m})$, Donghuzorun $(4452 \mathrm{~m})$, etc. Some ancient glaciers located on the both slopes were over $40 \mathrm{~km}$ long. In the above paragraph "General characteristics of the Pleistocene glaciations" the pecular distribution of ancient glaciers in Upper Svanetia (Enguri basin) has been mentioned. Namely, glacier protrusion from the side valley into the main valley free of ice, as well as ice sliding across the Ugviri pass, etc. These facts have been confirmed by detailed petrographic study of moraines and their sources [19] [20].

To the east from the Mamisoni pass, at a distance of $156 \mathrm{~km}$, up to Shaviklde ( $45^{\circ} 30^{\prime}$ E.L.) the Main Range is up to $4000 \mathrm{~m}$ above the sea level and its contemporary glaciers are scattered on separate, highest mountains (Khalatsa, Chaukhi etc.). On the Forerange (Khokhi, Pirikitis etc. ranges) the contemporary glaciers cover a considerable area. The Ancient Glaciation of this part of the Greater Caucasus was not entire. It was broken at low areas of the Main Range and river valleys crossing the Forerange (rivers Ardon, Terek, Assa, Argun). The largest Pleistocene glaciers of the Main Range were connected with the Chaukhi, Didgverdi, Khalatsa, Zilgakhokh mountains and were 8 - $12 \mathrm{~km}$ long (Abudelauri, Alazani, Terek and other glaciers). Among the side southern ranges, only the glaciers Britata, Knogi, Batsgadi, etc., slid 5 - 7 km down from Germikha Range to the valleys of Large and Small Liakhvi (at present the Germukha Range is totally deprived of ice cover). The larger glaciers lay on the slopes of the Forerange. They slipped down the Dzimaraikhokh, Kazbegi, Dakuekhi, Shan and other mountains, along the river valleys of Gizeldon, Suatisidon, Genaldon, Maitsistskali. The Terek basin has been the subject of discussion among the scientists, as it was mentioned above. Some authors (Reinghard [12], Bereznjakov [16] and others) contended, that $80 \mathrm{~km}$ long "the Great Terek Glacier" existed in the past, reached Terek and Sunzhen ranges in the Precaucasus being branched into numerous tributaries in the upper part. The study of lithological composition of deposits of the Terek valley, Osetian sloping plain and the above mentioned ranges made the opposite group of scientists (Vardaniants [14], Maruashvili [15], Velikovskaja, Kozhevnkov [17], etc.) to conclude, that such a powerful glaciation in Terek basin was unreal. Following L.A. Vardaniants [14] the scientists consider the volcanoglacial mudflows (lahars) as the main factor of transportation of huge blocks of the Kazbegi and Kabarjina massifs along the Terek river valley.

\section{Conclusions}

The last stage of glaciers advance in the Caucasus is comparatively well-known. This stage of the XVII-XIX centuries is called sometimes "Minor glacial epoch" 
or the Fernau stage. It is explained by well preserved corresponding moraines and the existence of Russian topographic maps of the second half of the XIX century. During the last 90 - 100 years, large valley glaciers Bezengi, Tsanner, Karaugom, etc., reduced by $1-1.5 \mathrm{~km}$, while some small glaciers disappeared completely. During the last 50 years, the Kvitlod and Laboda glaciers separated from the Tviber and Zopkhito glaciers and became independent. Practicability of glacier passes has also changed (e.g. Midagrabin Pass between the Terek and Gezeldoni upper reaches, once very convenient for horseman, became hardly passable for foot passengers due to the reduction of the Midagrabin glacier). However, the maximum advance of the Caucasian glaciers to the stage of the XVII-XIX centuries, is still scantily studied, as in the XVIII century and the first-half of the XIX century, the large scale topographic survey was not applied in the Caucasus.

Some authors stick to the idea that Caucasian glaciations were caused or intensified by the influence of South European covering glaciation and hence were delayed, in comparison with the latter [22]. Such an outlook can hardly be admitted due to a large distance between the Caucasus and the side of European glacial shield (above $800 \mathrm{~km}$ during the Rissian and $1700 \mathrm{~km}$ during the Wurmian). It is well-known, that the cooling influence of large ice sheets on periglacial zone spreads up to $150-200 \mathrm{~km}$ only. We believe that mountain glaciers of the Caucasus and the Alps reached their maximum development earlier than the covering glaciation of the high latitudes, the growth of which was delayed by many centuries, in connection with the autofluctuation process. The Caucasian glaciations were influenced by the global changes of atmospheric circulation and regional tectonic movements.

For the future, complex researches are planned for the Lesser Caucasus and Javakheti plateau, where special attention will be paid to the issues of changes in paleoclimate and in geographical environment. It is obvious that the questions of ancient glaciation will be correlated with issues related to the glaciation of the Main Caucasus.

\section{References}

[1] Abich, H. (1872) Etudes sur les glaciers actuels et anciens du Caucase. Sbornik svedenyi o Cavcase, I, 85-127.

[2] Maruashvili, L.I. (1956) Revision Advisability of the Existing Ideas on Paleogeoggraphical Conditions of the Glaciation Period at the Caucasus. The Academy of Sciences of the Georgian SSr, Tbilisi.

[3] Khazaradze, R.D. and Kharadze, K. (2014) Recent and Old Glaciations of Tusheti, Materials of the Commission on the Complex Study of the Problems of Highland. Georgian National Academy of Sciences, 264-281.

[4] Khazaradze, R.D. (2010) Paleoglacial Mudflow Processes in High Mountainous Regions of Georgia (the Tergi Riverhead). Materials of the Commission on the Complex Study of the Problems of Highland. Georgian National Academy of Sciences, 95-108.

[5] Khazaradze, R.D., Kharadze K. and Tsikarishvili K. (2016) Activation of Natural 
Distructive Processes in the Territory of Kazbegi Municipality (Devdoraki GlacialMudflow Case Study). Science and Technologies, 1, 76-88.

[6] Khazaradze, R.D. (2016) Fluctuations of Paleoclimate and Geographical Environment on the Territory of Western Georgia in the Holocene. Science and Technologies, 3, 47-53.

[7] Khazaradze, R.D., Kharadze, K. and Chaladze, T. (2017) Variability of Paleoclimate and Geographical Environment on the Territory of Eastern Georgia in the Holocene. Science and Technologies, 2, 69-75

[8] Gudjabidze, G.E. (2003) Geological Map of Georgia (Scale 1: 500 000). Georgian State Department of Geology and National Oil Company "Saknavtobi", Tbilisi, Georgia.

[9] Khazaradze, R.D. (2004) Pleistocene Glaciation of the Great Caucasus, Tbilisi.

[10] Krasnov, A.N. (1891) The Upland Flora of Svaneti and Peculiarities of Its Grouping, Depending on the Present Day Living Conditions and the Influence of Glacial Period. Izvestija Russkogo Geograficheskogo obschestva, 5, 357-383.

[11] Reinghard, A.L. (1933) The Glacial Period at the Caucasus and Its Relation with Glaciation of the Alps and Altai. Trudy II Mezhdunarodnoi konferentsii Asstsiatsii po izucheniju chetvertichnogo periodsEvropy, II, 3-14.

[12] Reinghard, A.L. (1941) Neskolko slov o drevney morene u Cebeldy na Kavkaze. Trudy Sovetsk. sekcyi Mezhdunarodnoi assoc. po isuchen. Chetvert. perioda, 5, 1941, 62-64.

[13] Fedorov, P.V. and Getner, A.P. (1959) K stratigrafyi cetvertichn. Otlojenyi pribrejnoy polosi Severo-vost. Prichernomorya. Trudy geologicheskogo instituta $A H$ GSSR, 32, 143-158.

[14] Vardanjantz, L.A. (1948) The Post-Pliocene History of the Caucasian _ Block Sea Caspian Sea Region. The Academy of Seiences of the Armenian SSR, Erevan, 4-184.

[15] Maruashvili, L.I. (1955) Fsevdomorena u Cebeldy. Trudy AN SSSR, VI, 87-101.

[16] Bereznjakov, A.I. (1965) Petrographic Characteristic of Problematic Coarse Deposits in the Vicinity of Village Khevi. Materialy Kavkazskoy ezpeditsii (po programe Mezhdunarodnogo Geofizicheskogo goda), 5, 112-113.

[17] Velikovskaya, E.M. and Kozhevnikov, A.V. (1959) On the Origin of Moraine like Strata in the Valleys of Terek, Gizeldon and Urukh. Vestnik Moskovskogo Univeriteta, 4, 125-134.

[18] Paffengoltz, K.N. (1958) Nev Data on Stratigraphy of Lavas of the Kazbegi Region and Kheli Volcanic Plateau (The Central Caucasus) and the Ancient Glaciation of the Area. Sovetskaya geologyia, 12, 115-139.

[19] Khazaradze, R.D. (1971) Methods of Determination of the Ancient Glaciers Direction in the Upper Svaneti Based on the Study of Morainic Material Lithology. Soobsvhenija Akademii Nauk Gruzinskoi SSR, 61, 621-624. (In Georgian)

[20] Khazaradze, R.D. (1974) Granicy chetvertichnogo oledeneniya verxney Svanetyi. Soobchenie AN GSSR, 2, 377-380.

[21] Maruashvili, L.I. (1969) Drevnee oledenenie baseyna r. Khevsuretskoy Aragvi i ego znachenie dlya razrabotki obschikh voprosov paleoglyaciologyi. Itogovaya nauchnaya sessyia In-ta geographyi im. Vakhushti AN GSSR, 3-5.

[22] Tsereteli, D.V. (1966) Pleistocene Deposits in Georgia. Publishing House Metsniereba, Tbilisi.

[23] Maruashvili, L.I. (1975) The Valley Planation of Uplifted Mountain Systems. The Caucasus as an Example. Geomorpologiya, 4, 12-21. 